\title{
Digestible tryptophan levels in diets for pigs weighing 15 to $30 \mathrm{~kg}$
}

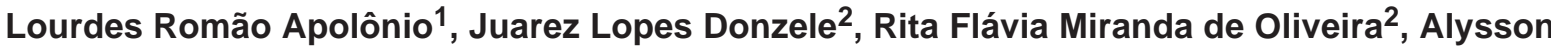 Saraiva ${ }^{1}$, Francisco Carlos de Oliveira Silva ${ }^{3}$, Aloízio Soares Ferreira ${ }^{2}$, Anderson Lazarini Lima $^{1}$, João Luís Kill ${ }^{4}$}

\author{
1 Programa de Pós-graduação em Zootecnia. \\ 2 DZO/UFV. \\ ${ }^{3}$ EPAMIG. \\ ${ }^{4}$ UVV.
}

ABSTRACT - In order to evaluate the effects of increasing dietary tryptophan levels on performance and carcass characteristics of growing pigs, a total of 60 crossbred castrated male pigs, with average initial and final body weights of $15.50 \pm 1.15$ and $30.60 \pm 1.35 \mathrm{~kg}$ were used. Pigs were allotted in a completely randomized block design, with five dietary treatments $(0.149,0.158,0.168,0.177$, and $0.187 \%$ digestible tryptophan, corresponding to digestible tryptophan:lysine relations of 16.0 , 17.0, 18.0, 19.0, and 20.0\%), six replicates, and two animals per experimental unit, which was represented by the pen. Experimental diets and water were supplied ad libitum throughout the experimental period. The average maximum and minimum temperatures inside the rooms were of $21.5 \pm 1.12^{\circ} \mathrm{C}$ and $26.4 \pm 1.91^{\circ} \mathrm{C}$, respectively. There was no effect of digestible tryptophan on daily feed intake or protein deposition of pigs. Body weight gain increased quadratically with increasing digestible tryptophan in the diets up to $0.175 \%$ maximum response. Increasing digestible tryptophan in the diets linearly improved feed conversion of pigs. The greatest weight gain of 15 to $30 \mathrm{~kg}$ castrated male pigs is obtained at $0.175 \%$ digestible tryptophan, corresponding to a digestible tryptophan:lysine relation of $18.82 \%$ and an estimated daily intake of 2.32 grams of digestible tryptophan.

Key Words: amino acids, ideal protein, performance, protein deposition

\section{Introduction}

Feed formulation based on the values of amino acid digestibility of ingredients and application of the ideal protein concept - understood as the balance of feed amino acids capable of supplying without excesses or deficiencies the requirements of all amino acids necessary for proper maintenance of the growth - has made it possible for nutritionists to obtain diets with lower protein levels, without impairing the performance of pigs. In this concept, lysine, because of its constancy in body protein and its preferential metabolic destination for deposition of lean tissue (Kessler, 1998), has been used as reference for the establishment of the requirements of other essential amino acids, expressed as a relation or percentage of the value of digestible lysine in the diet.

Tryptophan is an essential amino acid in the nutrition of piglets and growing-finishing pigs (NRC, 1998), and in diets in which corn is used as the main ingredient, tryptophan becomes the fourth limiting amino acid, after lysine, methionine and threonine. Limiting levels of tryptophan in the diet, compared with other essential amino acids, influence negatively the synthesis of protein, weight gain and feed efficiency of the animals (Le Floc'h \& Seve, 2007; Jansman, 2010).

In addition to its function as an amino acid essential to protein synthesis, tryptophan is the sole source of substrate for the synthesis of important components such as serotonin, a neurotransmitter that stimulates feed intake by animals (Henry et al., 1992). Tryptophan can also be metabolized through the kynurenine pathway, associated with the defense of the body and immune response modulation (Moffett \& Namboodiri, 2003; LeFloc'h \& Seve, 2007).

Digestible tryptophan requirements for piglets in the nursery phase have been investigated, but few studies have been carried out for the determination of requirements of this amino acid by growing pigs, with results varying for different studies (Guziketal., 2005). The variations in estimates of digestible tryptophan requirement of growing pigs, reported in the literature, may be caused by the differences among genotypes and sanitary standards of the animals, level of dietary protein and digestibility of the tryptophan of the feed ingredients (Guziketal., 2005).

The objective of this study was to evaluate the effect of levels of digestible tryptophan and the tryptophan: digestible lysine relation in diets for pigs from 15 to $30 \mathrm{~kg}$. 


\section{Material and Methods}

The experiment was conducted in a nursery in Setor de Suinocultura in Departamento de Zootecnia at Universidade Federal de Viçosa, Minas Gerais.

The experiment consisted of 60 hybrid commercial barrows, with initial weight of $15.50 \pm 1.15 \mathrm{~kg}$, allotted to a completely randomized block design, with five treatments (0.149, 0.158, 0.168, 0.177 and $0.187 \%$ digestible tryptophan, corresponding to relationships 16.0, 17.0, 18.0, 19.0 and $20.0 \%$ with digestible lysine), six replicates and two animals per pen, which was considered the experimental unit. In the formation of the blocks, initial weight and degree of kinship of the animals were considered.

Animals were housed in suspended metal cages with floor and side screened, equipped with semi-automatic feeders and nipple drinkers, located in masonry buildings with concrete floor and lowered wooden ceiling. Temperature inside the room was measured daily at 8 p.m., through maximum and minimum thermometer, kept in an empty cage in the middle of the room, at half of the animals' height.

Experimental iso caloric and iso nitrogenous diets (Table 1) were composed primarily of corn and soybean meal to meet the animal requirements for energy, minerals, vitamins and amino acids, according to Rostagno et al. (2000), except for tryptophan. To ensure that no other essential amino acid other than tryptophan was deficient in diets, the relationships of these amino acids with lysine were above those recommended in the ideal protein for animals at the same stage of growth, according to Rostagno et al. (2000).

The treatments, which consisted of different levels of digestible tryptophan, were composed of a basal diet and other four diets obtained by supplementing the basal diet with L-tryptophan in substitution of glutamic acid, proportionally to the concentrations of nitrogen.

Table 1 - Percentage of calculated compositions of experimental diets

\begin{tabular}{|c|c|c|c|c|c|}
\hline \multirow[t]{2}{*}{ Ingredient } & \multicolumn{5}{|c|}{ Available tryptophan level (\%) } \\
\hline & 0.149 & 0.158 & 0.168 & 0.177 & 0.187 \\
\hline Corn & 74.090 & 74.090 & 74.090 & 74.090 & 74.090 \\
\hline Bone and meat meal & 5.000 & 5.000 & 5.000 & 5.000 & 5.000 \\
\hline Glutamic acid & 0.100 & 0.087 & 0.073 & 0.060 & 0.045 \\
\hline Starch & 0.100 & 0.104 & 0.108 & 0.112 & 0.117 \\
\hline L-lysine (78\%) & 0.331 & 0.331 & 0.331 & 0.331 & 0.331 \\
\hline L-threonine (98\%) & 0.122 & 0.122 & 0.122 & 0.122 & 0.122 \\
\hline L-tryptophan (98\%) & - & 0.009 & 0.019 & 0.028 & 0.038 \\
\hline L-valine (98\%) & 0.004 & 0.004 & 0.004 & 0.004 & 0.004 \\
\hline Soybean oil & 0.982 & 0.982 & 0.982 & 0.982 & 0.982 \\
\hline Dicalcium phosphate & 0.225 & 0.225 & 0.225 & 0.225 & 0.225 \\
\hline BHT & 0.010 & 0.010 & 0.010 & 0.010 & 0.010 \\
\hline \multicolumn{6}{|l|}{ Nutritional calculated composition ${ }^{3}$} \\
\hline Crude protein (\%) & 17.458 & 17.458 & 17.458 & 17.458 & 17.458 \\
\hline ME (kcal/kg) & 3222 & 3222 & 3222 & 3222 & 3222 \\
\hline Digestible lysine (\%) & 0.930 & 0.930 & 0.930 & 0.930 & 0.930 \\
\hline Digestible tryptophan (\%) & 0.149 & 0.158 & 0.168 & 0.177 & 0.187 \\
\hline Digestible met + cys (\%) & 0.555 & 0.555 & 0.555 & 0.555 & 0.555 \\
\hline Digestible threonine (\%) & 0.632 & 0.632 & 0.632 & 0.632 & 0.632 \\
\hline Digestible isoleucine (\%) & 0.566 & 0.566 & 0.566 & 0.566 & 0.566 \\
\hline Digestible valine (\%) & 0.656 & 0.656 & 0.656 & 0.656 & 0.656 \\
\hline Sodium (\%) & 0.180 & 0.180 & 0.180 & 0.180 & 0.180 \\
\hline
\end{tabular}


Diets and water were supplied ad libitum to animals troughout the experimental period. Animals were weighed at the beginning and end of the experiment for determination of weight gain. Experimental diets were weighed when fed to the animals and the leftovers were weighed daily to determine feed intake, feed conversion and digestible tryptophan intake.

At the end of the trial, when animals reached the average weight of $30.60 \pm 1.35 \mathrm{~kg}$, they were submitted to a 24-hour feed fast. After this period, one animal from each experimental unit, with weight closest to $30 \mathrm{~kg}$, was slaughtered by exsanguination, then shaved and eviscerated.

An additional group of five piglets weighing $14.9 \pm 1.60 \mathrm{~kg}$ were slaughtered by following the same procedure used in the slaughter of animals in experiments for determining the initial composition of the carcass.

Whole, eviscerated and blood free carcasses of slaughtered animals were divided longitudinally and the left half of each carcass (including head and feet) was crushed for 15 minutes in a commercial 30-hp and 1775-rpm cutter. After homogenization of the crushed material, samples were taken from carcasses, which were stored in a freezer at $-12^{\circ} \mathrm{C}$.

After that, samples were thawed at room temperature for a 24-hour period and then submitted to pre-drying process in a forced ventilation oven at $65^{\circ} \mathrm{C}$ for 72 hours. Because of the high fat concentration, the samples were submitted to a hot pre-defatting (Soxhlet extractor) during four hours. Pre-dried and pre-defatted samples were ground in a ball mill and placed in identified glasses for further laboratory analyses.

Protein analyses of carcass samples were performed in Laboratório de Nutrição Animal in Departamento de Zootecnia at Universidade Federal de Viçosa, according to techniques described by Silva (2002).

The deposition of protein in the carcass was evaluated by comparative criteria between carcasses of contemporaries animals slaughtered at $15.55 \pm 0.75 \mathrm{~kg}$ and the animals slaughtered at the end of the experiment, one animal from each experimental unit with weight closer to the average weight of its respective unit, according to the methodology proposed by Donzele et al. (1992).

The parameters evaluated were: average daily gain, feed intake, feed conversion, daily digestible tryptophan intake and daily protein deposition.

Performance variables and the deposition of protein were analyzed by the SAEG (Statistical Analysis System and Genetics) software version 8.0, developed at Universidade Federal de Viçosa (UFV, 2000), using the procedures for the analysis of variance and regression, according to the following statistical model:

Yijk $=\mu+B i+T j+e i j k$

in which: Yijk = observed characteristic; $\mu=$ general trait mean; $\mathrm{Bi}=$ effect of block $\mathrm{i}, \mathrm{I}=1,2 \ldots$ and $6 ; \mathrm{Tj}=$ effect of level of digestible tryptophan $\mathrm{j} ; \mathrm{j}=1,2 \ldots$ and 5 ; eijk = random error associated with each observation.

Levels of digestible tryptophan in the diet which provided the best results of performance and protein deposition were determined by linear regression analysis, quadratic and/or discontinuous Linear Response Plateau model (LRP) according to the best data adjustment for each variable studied.

\section{Results and Discussion}

During the experimental period, average minimum and maximum temperatures inside the rooms were $21.5 \pm 1.12^{\circ} \mathrm{C}$ and $26.4 \pm 1.91^{\circ} \mathrm{C}$, respectively. Considering that the ideal temperature range for pigs during growth, suggested by Coffey et al. (2000), is from 18 to $28^{\circ} \mathrm{C}$, it was found that the animals were not submitted to heat stress based on temperature variation occurred in this study.

There was no effect $(\mathrm{P}>0.05)$ of levels of digestible tryptophan on the daily feed intake of animals (Table 2). Similarly, Susenbeth \& Lucanus (2005) also found no effect of increasing levels of tryptophan in the diet on daily feed intake of pigs from 15 to $22 \mathrm{~kg}$.

Table 2 - Data of performance and protein deposition of 15 to $30 \mathrm{~kg}$ piglets fed on diets with different levels of digestible tryptophan

\begin{tabular}{lccccc}
\hline Variable & \multicolumn{3}{c}{ Digestible tryptophan (\%) } & \multicolumn{1}{c}{ CV (\%) } \\
\cline { 2 - 5 } & 0.149 & 0.158 & 0.168 & 0.177 & 0.187 \\
\hline Average feed intake (g/d) & 1261 & 1325 & 1398 & 1329 & 1332 \\
Tryptophan intake (g/d) $^{1}$ & 1.88 & 2.09 & 2.35 & 2.35 & 2.49 \\
Average weight gain (g/d) $^{2}$ & 686 & 729 & 783 & 776 & 761 \\
Feed conversion (g/g) $^{2}$ & 1.84 & 1.77 & 1.78 & 1.72 & 1.75 \\
Protein deposition (g/day) & 72.25 & 82.28 & 74.18 & 71.17 & 75.77 \\
\hline
\end{tabular}

${ }^{1}$ Linear $(\mathrm{P}<0.05)$.

2 Quadratic $(\mathrm{P}<0.05)$. 
However, the result of daily feed intake observed in this study is not consistent with those reported by Guzik et al. (2005), who, when evaluating tryptophan levels in diets for piglets from 7 to $15 \mathrm{~kg}$, with tryptophan:digestible lysine relation ranging from 14.5 to $19.5 \%$, found a linear increase in feed consumption of piglets by increasing digestible tryptophan levels in the diets. Similarly, Zhang et al. (2007) investigated the effects of digestible tryptophan varying from 0.12 to $12.26 \%$ in diets for weanling pigs and also found positive relationship between levels of digestible tryptophan in the diet and daily feed intake.

In more recent studies, Fernandez \& Strathe (2009) and Jansman et al. (2010) also found variation in daily feed intake of piglets by increasing the levels of this amino acid in the diet.

The inconsistency of results noted among studies regarding the effects of digestible tryptophan levels on the daily feed intake may be due, among other factors, to the relationship between digestible tryptophan and neutral long chain amino acids (NLCAA) e.g., leucine, isoleucine, valine, phenylalanine and tyrosine from experimental diets. According to Henry et al. (1992), tryptophan competes with NLCAA for sharing the same transport system for passage through the blood-brain barrier. Thus, a reduced plasma ratio between tryptophan and NLCAA results in decreased availability of tryptophan in the brain, thus reducing the production of serotonin, a neurotransmitter that stimulates feed intake by animals.

In a later study, Henry et al. (1996) confirmed that the reduction in involuntary intake of feed by pigs fed on diets deficient in tryptophan or with excess of protein may be related to lower levels of serotonin in various parts of the brain, and this effect was more pronounced in females when compared with barrows.

Effect $(\mathrm{P}<0.01)$ of levels of dietary digestible tryptophan on the daily consumption of digestible tryptophan by the pigs was observed, increasing linearly (Table 2) according to the equation $\hat{Y}=-0.7025+17.6492 \operatorname{Trp}\left(r^{2}=0.90\right)$. Because daily feed intake of animals did not vary significantly among treatments, the linear increase in digestible tryptophan intake may be explained by its concentration in the feed.

Digestible tryptophan levels affected $(\mathrm{P}<0.05)$ daily weight gain (DWG) of animals (Table 2), which increased quadratically up to the estimated level of $0.175 \%$, corresponding to a ratio with digestible lysine of $18.82 \%$ (Figure 1). Similar results were obtained by Han et al. (1993), who evaluating levels of digestible tryptophan from 0.08 to $12.15 \%$ in diets for pigs from 10.9 to $22.0 \mathrm{~kg}$, also found a linear increase in weight gain by increasing dietary levels

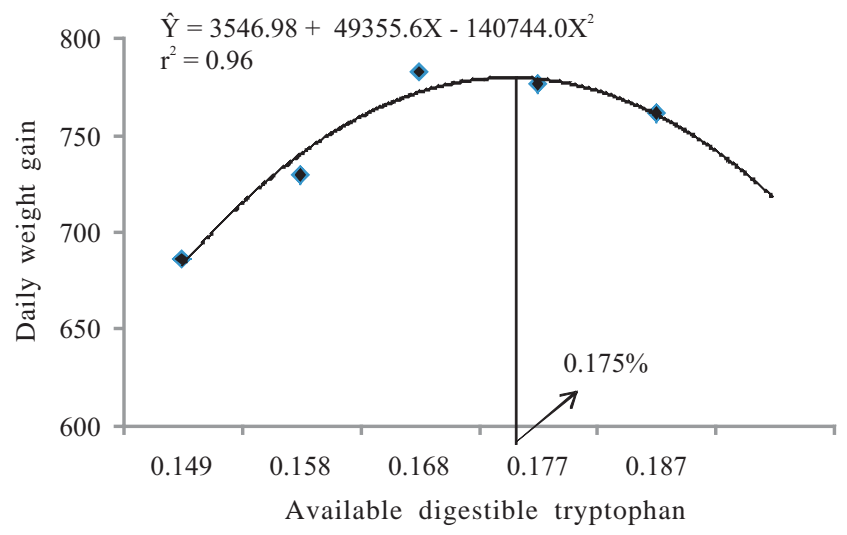

Figure 1 - Daily weight gain of pigs from 15 to $30 \mathrm{~kg}$ fed diets with different levels of available digestible tryptophan.

of tryptophan, with best response for this variable obtained at the level of $0.137 \%$ of digestible tryptophan. Despite the similar response pattern as a result of the increased levels of digestible tryptophan on daily weight gain observed in the studies, the level of digestible tryptophan $(0.175 \%)$ which provided best result of daily weight gain in animals in this study was $28 \%$ higher than the one obtained by Han et al. (1993). Positive effect by the addition of tryptophan into diets on weight gain of piglets in the initial growth phase was also observed by many authors (Burgoon et al., 1992; Sawadogo et al., 1997; Ferguson \& Gous, 2002; Pastuzewska et al., 2007; Fernandez \& Strathe, 2009; Jansman et al., 2010).

Conversely, Susenbeth \& Lucanus (2005), in a study with tryptophan supplementation $(0.2$ to $1.0 \mathrm{~g} / \mathrm{kg})$ in diets for barrows from 15 to $22 \mathrm{~kg}$, found no effect of tryptophan levels on weight gain of animals. According to the authors, a digestible tryptophan:lysine relation of 17.0 or $18.0 \%$ in diets for growing pigs seems to be sufficient to maximize the performance of animals, provided that the level of digestible lysine is adequate.

The digestible tryptophan:digestible lysine relation (18.82\%) observed in this study, in which the best value of DWG was obtained, was higher than that proposed by Chung \& Baker (1992) and by NRC (1998), which recommend a relation of $18 \%$ between these amino acids for piglets from 10 to 20 and from 20 to $50 \mathrm{~kg}$, respectively.

According to the report by Jansman et al. (2010), the level of digestible lysine used in experimental diets may be one of the factors that justify the variation of results observed among studies. Confirming this proposition, Eder et al. (2003) and Guzik et al. (2005) noted that the daily weight gain of pigs in the finishing phase was significantly influenced by the levels of dietary tryptophan, and the best 
responses were obtained at the levels of 0.146 and $0.096 \%$ of digestible tryptophan, respectively, which corresponded to the same relationship with digestible lysine of $18 \%$.

The level of digestible tryptophan $(0.175 \%)$ which provided the best response for weight gain of animals in this study is above the $0.150 \%$ level recommended by NRC (1998) for animals from 20 to $50 \mathrm{~kg}$ and the recommended $(0.168 \%)$ by Rostagno et al. (2005) for pigs of average performance at the same growth phase.

Digestible tryptophan levels affected $(\mathrm{P}<0.05)$ feed conversion (FC), which improved linearly (Table 2) according to the equation $\hat{\mathrm{Y}}=2.1654-2.3355 \operatorname{Trp}$ $\left(r^{2}=0.65\right)$. This response pattern is consistent with that obtained by Schutte \& Van Weerden (1988), who evaluating levels of digestible tryptophan from 0.13 to $0.25 \%$ for pigs from 11 to $37 \mathrm{~kg}$, found a linear improvement in feed conversion of the animals.

Positive influence of tryptophan levels on feed conversion of piglets was also observed by Guzik et al. (2002), who evaluating levels of digestible Trp (0.13 to $0.25 \%$ ) for weaned pigs, found an improvement in feed conversion, although the best response was obtained at the level of $0.18 \%$ of tryptophan. The results obtained in this study corroborate those of Guzik et al. (2005) and those of Fernandez \& Strathe (2009), who observed a linear increase in feed efficiency of piglets when the tryptophan:digestible lysine relation increased from 14.5 to $19.5 \%$ and from 16.0 to $22.0 \%$, respectively.

Conversely, Susenbeth \& Lucanus (2005) found no effect of the increase at the concentration of dietary digestible tryptophan on feed conversion of pigs from 15 to $22 \mathrm{~kg}$.

According to data obtained in this study, the requirement of digestible tryptophan by pigs from 15 to $30 \mathrm{~kg}$, for better feed conversion is greater than the necessary to increase the growth rate. However, this observation does not confirm the report of Susenbeth \& Lucanus (2005) that the requirement of digestible tryptophan for maximum weight gain is always greater than that needed for a better feed conversion.

There was no effect $(\mathrm{P}>0.05)$ of levels of digestible tryptophan on the daily protein deposition of pigs (Table 2 ). Combining the results of daily protein deposition with the results of feed conversion and daily weight gain obtained in this study, it can be inferred, biologically, that the daily protein deposition of animals observed in this study is inconsistent if considered that the increase in protein deposition in the carcass of pigs is one of the major factors that may explain the result of the increase in weight gain associated with improvement in feed conversion (Krick \&Boyd, 1992; Marinho et al., 2007).
Similarly to the result of daily protein deposition obtained in this study, Henry (1995), evaluating the effect of tryptophan on the performance of finishing pigs, also found no effect of tryptophan levels (from 0.10 to $0.13 \%$ ) on daily protein deposition of the animals when they were slaughtered at the same body weight. However, an increase in protein deposition was observed when animals were slaughtered at the same age. Thus, the fact that animals in this study had been slaughtered at the same body weight contributed to the absence of differences in the carcass parameters evaluated.

\section{Conclusions}

The level of $0.175 \%$ digestible tryptophan, corresponding to a tryptophan:digestible lysine relation of $18.82 \%$ and to an estimated daily consumption of $2.32 \mathrm{~g}$, provides the best result of weight gain of 15 to $30 \mathrm{~kg}$ castrated male piglets.

\section{References}

BURGOON, K.G.; KNABE, D.A.; GREGG, E.J. Digestible tryptophan requirements of starting, growing, and finishing pigs. Journal of Animal Science, v.70, p.2493-2500, 1992.

COFFEY, R.D.; PARKER, G.R.; LAURENT, K.M. [2000]. Feeding growing-finishing pigs to maximize lean grow rate. College of Agriculture: University of Kentucky. Available at: <http://www.animalgenome.org/edu/PIH/prod_grow_finish.pdf> Accessed on: May 14, 2007.

CHUNG, T.K.; BAKER, D.H. Ideal amino acid pattern for 10 kilogram pigs. Journal of Animal Science, v.70, p.3102-3111, 1992.

DONZELE, J.L.; COSTA, P.M.A.; ROSTAGNO, H.S. et al. Efeito dos níveis de lisina na composição da carcaça de suínos de 5 a 15 kg. Revista da Sociedade Brasileira de Zootecnia, v.21, p.1091-1099, 1992.

EDER, K.; NONN, H.; KLUGE, H. et al. Tryptophan requirement of growing pigs at various body weights. Journal of Animal Science, v.87, p.336-346, 2003.

FERGUSON, N.S.; GOUS, R.M. The response of growing pigs to amino acids as influenced by environmental temperature: tryptophan. British Society of Animal Science, v.74, p.103-110, 2002.

FERNÁNDEZ, J.A.; STRATHE, A. Dietary tryptophan and threonine supply to 28 days old weaned piglets. Animal Feed Science and Technology, v.154, p.265-270, 2009.

GUZIK, A.C.; SOUTHERN, L.L.; BIDNER, T.D. et al. The tryptophan requirement of nursery pigs. Journal of Animal Science, v.80, p.2646-2655, 2002.

GUZIK, A.C.; PETTITT, M.J.; BELTRANENA, E. et al. Threonine and tryptophan ratios fed to nursery pigs. Journal of Animal Physiology and Animal Nutrition, v.89, p.297-302. 2005.

HAN, Y.; CHUNG, T.K.; BAKER, D. H. Tryptophan requirement of pigs in the weight category 10 to 20 kilograms. Journal of Animal Science, v.71, p.139-143, 1993.

HENRY, Y. Effects of dietary tryptophan deficiency in finishing pigs, according to age or weight at slaughter or live weight gain. Livestock Production Science, v.41, p.63-76, 1995.

HENRY, Y.; SÈVE, B.; MOUNIER, A. et al. Growth performance and brain neurotransmitters in pigs as affected by tryptophan, protein, and sex. Journal of Animal Science, v.74, p.2700-2710, 1996. 
HENRY, Y.; SÈVE, B.; COLLÉAUX, Y. et al. Interactive effects of dietary levels of tryptophan and protein on voluntary feed intake an growth performance in pigs, in relation to plasma free amino acids and hypothalamic serotonin. Journal of Animal Science, v.70, p.1873-1887, 1992.

JANSMAN, A.J.M.; DIEPEN, J.T.M.; MELCHIOR, D. The effect of diet composition on tryptophan requirement of young piglets. Journal of Animal Science, v.88, p.1017-1027, 2010.

KESSLER, A.M. Exigências nutricionais para máximo rendimento de carne em suínos. In: SIMPÓSIO SOBRE RENDIMENTO EQUALIDADE DA CARNE SUÍNA, 1998, Concórdia. Anais... Concórdia: EMBRAPA-CNPSA, 1998. p.18-25.

KRICK, B.J.; BOYD, R.D. Influence of genotype and sex on the response of growing pigs to recombinant porcine somatotropin. Journal of Animal Science, v.70, p.3024-3034, 1992.

LE FLOC'H, N.; SEVE, B. Biological roles of tryptophan and its metabolism: potential implications for pig feeding. Livestock Science, v.112, p.23-32, 2007.

MARINHO, P.C.; FONTES, D.O.; SILVA, F.C.O. et al. Efeito da ractopamina e de métodos de formulação de dietas sobre o desempenho e as características de carcaça de suínos machos castrados em terminação. Revista Brasileira de Zootecnia, v.36, p.1061-1068, 2007 (supl.).

MOFFET, J.R.; NAMBOODIRI, M.A. Tryptophan and immune response. Immunology and Cell Biology, v.81, p.247-265, 2003.

NATIONAL RESEARCH COUNCIL - NRC. Nutrient requirements of swine. 3.ed. Washington, D.C.: National Academy Press, 1998. 189p.
PASTUSZEWSKA, B.; TOMASZEWSKA-ZAREMBA, D.; BURACZEWSKA, L. et al. Effects of supplementing pig diets with tryptophan and acidifier on protein digestion and deposition, and on brain serotonin concentration in young pigs. Animal Feed Science and Technology, v.132, p.49-65, 2007.

ROSTAGNO, H.S.; ALBINO, L.F.T.; DONZELE, J.L. et al. Tabelas brasileiras para aves e suínos: composição de alimentos e exigências nutricionais. Viçosa, MG: UFV, 2005. 181p.

ROSTAGNO, H.S.; ALBINO, L.F.T.; DONZELE, J.L. et al. Tabelas brasileiras para aves e suínos: composição de alimentos e exigências nutricionais. Viçosa, MG: UFV, 2000. 141p.

SAWADOGO, M.L.; PIVA, A.; PANCIROLI, A. et al. Marginal efficiency of free or protected crystalline L-tryptophan for tryptophan and protein accretion in early-weaned pigs. Journal of Animal Science, v.75, p.1561-1568, 1997.

SCHUTTE, J.B.; VAN WEERDEN, E.J. Utilization of DL-tryptophan in young pigs. Animal Production, v.46, p.447-452, 1988.

SILVA, D.J.; QUEIROZ, A.C. Análise de alimentos (métodos químicos e biológicos). 3.ed. Viçosa, MG: Universidade Federal de Viçosa, 2002. 235p.

SUSENBETH, A.; LUCANUS, U. The effect of tryptophan supplementation of diets of restricted and unrestricted young pigs. Journal Animal Physiology and Animal Nutrition, v.89, p.331-336, 2005.

UNIVERSIDADE FEDERAL DE VIÇOSA - UFV. SAEG -Sistemas de Análises Estatísticas e Genéticas. Versão 9.0. Viçosa, MG, 2000. (CD-ROM).

ZHANG, G.; YIN, J.; LI, D. et al. Tryptophan enhances ghrelin expression and secretion associated with increased food intake and weight gain in weanling pigs. Domestic Animal Endocrinology, v.33, p.47-61, 2007. 